Article

\title{
Long-Term Changes in Cork Oak and Holm Oak Patches Connectivity. The Algarve, Portugal, a Mediterranean Landscape Case Study
}

\author{
Nuno de Santos Loureiro (D) and Maria Jacinta Fernandes* \\ Departamento de Ciências da Terra, do Mar e do Ambiente, FCT—Universidade do Algarve, \\ 8005139 FARO, Portugal; nlourei@ualg.pt \\ * Correspondence: mfernan@ualg.pt
}

Citation: Loureiro, N.d.S.;

Fernandes, M.J. Long-Term Changes in Cork Oak and Holm Oak Patches Connectivity. The Algarve, Portugal, a Mediterranean Landscape Case Study. Environments 2021, 8, 131. https://doi.org/10.3390/ environments8120131

Academic Editor: Christine Fürst

Received: 6 October 2021

Accepted: 17 November 2021

Published: 23 November 2021

Publisher's Note: MDPI stays neutral with regard to jurisdictional claims in published maps and institutional affiliations.

Copyright: (c) 2021 by the authors. Licensee MDPI, Basel, Switzerland. This article is an open access article distributed under the terms and conditions of the Creative Commons Attribution (CC BY) license (https:// creativecommons.org/licenses/by/ $4.0 /)$.

\begin{abstract}
Structural connectivity can be inferred by several landscape metrics that appear to be relevant for characterizing how landscapes constrain or favor the presence and movement of animal species at the level of the regional landscape. Trends of change can be estimated trough spatial time-series analysis. The use of historical maps increases the time span of analysis of the landscape dynamic, relative to the use of remote sensing-related information. Supported by GIS, in this study, a framework for the analyses of the long-term trends of change in the connectivity of the Algarve regional landscape was used to seize the possibility of expanding the span of the spatial time series by integrating an unpublished agricultural and forest map from the turn of the 19th to the 20th century with another historical map and two recent maps. The total area covered by cork and holm oak-related community patches and their connectivity increased over the 20th century and stabilized in the 21st century. A reflection on Portuguese contemporary land-cover policies is urged, to face the sustainable planning and management challenges concerning biodiversity.
\end{abstract}

Keywords: landscape connectivity; structural connectivity; regional landscape; cork oak; holm oak; forest and agroforestry thematic maps; historical maps; recent maps; GIS

\section{Introduction}

Changes in land use and land occupation transform landscape configuration. The main forces of change, such as deforestation, are well-documented as increasing forest fragmentation and reducing landscape connectivity [1-3]. Landscape connectivity refers to the ease with which organisms can move in a landscape [4]. According to their different dispersal capabilities, species flow within and between habitat patches [5]. Decreasing connectivity alters the flow of species through the landscape, ultimately resulting in a reduction of biodiversity [6]. Functional connectivity focuses on the behavioral responses of an organism to the habitat landscape elements, and therefore requires information about the species behavior, while structural connectivity focuses on habitat contiguity or distances between habitat patches [7] and can be inferred by landscape metrics [8]. Since it is, generally, difficult to measure the movement of organisms within a landscape using direct observation, landscape ecologists often rely on the analysis of spatial and temporal patterns of landscape connectivity [9]. Structural connectivity metrics, such as the area of habitat patches and distance between them, could be accounted for using, mainly, satellite imagery supported by GIS landscape mapping. These metrics have appeared to be relevant for characterizing how landscapes constrain or favor the presence and movement of animal species.

At the terrestrial landscape level, biodiversity is very sensitive to land-cover and land-use (LCLU) change. A high degree of influence of land use history in a landscape, chronic disturbance factors such agriculture and fire regimes, impacts the vegetation and habitats. LCLU change is expected to have the largest impact on global biodiversity in the 
21st century [10]. Therefore, the maintenance and promotion of landscape connectivity is one of the challenges for biodiversity conservation in fragmented landscapes. The study of landscape connectivity and the trend of it change is therefore an important issue for biodiversity and land-use planning. Landscape metrics related to connectivity are used as surrogate parameters to understand the patterns of biodiversity at the landscape level [11]. The development of spatial information on landscape metrics using spatial analysis tools, i.e., GIS, has become a robust process, although the different methodologies employed to classify land-use and land-cover types are usually limited to the span of the time series under analysis. Therefore, the analysis of land-use and land-cover change typically spans a period of a few decades to a little more than half a century. Recently, researchers have started to successfully integrate historical with recent maps, using GIS, to increase the time span of studies [12-16], for example, focusing on changes in forests over time [17,18].

The Mediterranean region has a long history of landscape disturbance. Agricultural land uses have been maintained for centuries and millennia and significant deforestation has historically occurred. Today, the region is also under pressure, and endangered by irreversible ecological damage, including the extinction of native plant species; the forest recovery process for native tree species and the conservation of biodiversity are therefore considered fundamental questions [19]. Due to historical disturbance the forest matrix disappeared a long time ago in the cultural landscapes of the Mediterranean region, replaced by a particular mosaic landscape pattern-the agro-silvo-pastoral lands. Located on the Iberian Peninsula, this type of land cover is known as montado (Portugal) or dehesas (Spain). It is an integrated and extensive system of land use resulting from prolonged human action, where crops, pasturelands, and scrublands, in juxtaposition or rotation, are shaded by a fairly closed to very open canopy of the native oaks. Cork oak (Quercus suber L.) and holm oak (Q. rotundifolia Lam.) are two perennial arboreous Fagaceae native from the Mediterranean region, and the most common native tree species in southern Portugal. The two species have a long history of interactions with humankind, subject of human overexploitation in Portuguese territory that has spanned centuries. Disturbances of cork and holm oaks woodlands over time have been related to fruit consumption by cattle, and occasionally humans, and cork-oak exploration for its bark and cork, which served various purposes. It also an encompassing wood for construction and energy production. Presently, both the native oaks species, woods and the montado are under protection by Portuguese and European Laws, related to nature and biodiversity conservation.

Accurate and detailed information regarding the historical spatial distribution of native oaks in Portugal does not exist. In 1886 the preparation of the first Portuguese agriculture and forest map started [20], but detailed and comprehensive cartographic information concerning the Algarve region only came available in the 1950s. Their use along with more recent maps, allowed the accurate description of the oaks' historical distribution for a period of about seven decades. In 2018, about a hundred of the original 1890-1900s chorographic-agricultural-forest drafts related to the Algarve and three map sheets that had never been edited were rediscovered in the archives of the Agriculture and Forest Portuguese Ministry. The possibility to expansively rewrite the history of the distribution of cork and holm oaks in the Algarve, for about twelve decades, emerged.

Making use of the unpublished historical LCLU information recently found, the present work aims at expanding the description of the history of the spatial distribution of dominant native oak tree species in the Algarve and allowing inference about the longterm trends of change of the regional forest landscape connectivity. To fix the challenge of analysing maps over longer time series, we built a framework integrating heterogeneous sources of information (LCLU historical and recent maps). The broader temporal retrospective here presented increases the knowledge about how land-use and land-cover changes impact the connectivity of the Mediterranean forest-related communities at the level of the regional landscape and contributes to the sustainable planning of land use and management challenges concerning biodiversity conservation in the Algarve. 


\section{Materials and Methods}

\subsection{Study Area}

The Algarve is the southernmost administrative territorial unit of mainland Portugal and a natural region. This strip of land, parallel to the sea with a roughly rectangular shape (extending from east to west about $140 \mathrm{~km}$, and from north to south about $40 \mathrm{~km}$ ), its total area is about $5000 \mathrm{~km}^{2}$, and it is located on the western extreme of the Iberian Peninsula, near the northwest Africa-Eurasia plate boundary [21]. The Algarve territory has distinguishing morphological and geological features within the Portuguese context. Two mountainous systems define the region's northern border, which contrast with the gentle topography of the inland neighbor region (Alentejo) and with the gently hilly Algarve downlands. In the east, the Guadiana River separates the Algarve from Spain; in the west and south, its littoral zone faces the Atlantic Ocean. Due to its geomorphological diversity, the region is usually considered to have three main ecological sub-regions or landscape units: the mountain chain (serra), the limestone area known as Barrocal, and the littoral area. The northern mountain system, with heights from about 200-400 m and a maximum of $900 \mathrm{~m}$ above sea level, is characterized by the predominance of incipient soils resulting from schists and greywackes. A thin strip of gres, ophites, basalt, and dolerite rocks, marks the transition to the limestone formation. Dominated by alkaline soils (red and yellow Mediterranean soils and clay-rich marly vertic soils), the Barrocal is a gently hilly fringe of land facing the sea. Cliffs, beaches, and dunes fields succeed each other at the littoral region, the narrow strip near the coast [22].

Biogeographically speaking, the Algarve territories are included in the designed Coastal Lusitania and West Andalusia Province of the Mediterranean Region [23]. With a strong oceanic influence, the Algarve has a thermo-mediterranean dominate bioclimate [24]. Displaying great natural value, with several rare endemic plants, seven climatophilous series describe the vegetation of the phyto-ecological subregions of the Algarve [24]. In most humid areas, the marcescent groves presence varies according to the soil characteristics: Querco alpestris-broteroi sigmetum over deep marly alkaline soils of the barrocal, a climatophilous relictual series, and Euphorbio monchiquensis-Querco canariensis sigmetum over mountain syenitic soils. In terms of potential distribution, the evergreen formations associated with the Q. suber and with the Q. rotundifolia dominate at the Algarve territory. Evergreen oak stands vary according to the soil characteristics, in dry to sub-humid ombrotype bioclimate areas: cork oak stands are found in the presence of Aro neglecti-Querco suberis sigmetum communities over sandy soils along the littoral strip; and the presence of Lavandulo viridis-Querco suberis sigmetum occurrs over schists and greywackes at the mountain system. In the driest places, holm oak dominates in two formations: Rhamno oleoidis-Querco rotundifoliae sigmetum, over the alkaline soils of the Barrocal, and Myrto communis-Querco rotundifoliae sigmetum dominates on the siliceous substrate. Occasionally, the Aro neglecti-Oleo sylvestris sigmetum occurs, over marly soils at subhumid to humid ombrotype areas.

Historically, the region has been visited and influenced by the Phoenicians and Carthaginians, Romans, Visigoths, Arabians, and Christians. Five centuries of Arabian occupation left important imprints on the landscape, at different levels-in the architecture and heritage, but also on the land use. The Arabians introduced the almond trees, fig trees and carob trees, the three species that form the traditional dry orchards that, even today, cover most of the Barrocal lands. During the Age of the Discoveries, the Algarve region played an important role. Cork-oak wood was, for a long time, the favorite for shipbuilding. The Portuguese maritime expansion was one of the main causes of the intensive logging of the stands of this native forest species [25]. In the absence of cork oak, holm-oak wood was one of the best alternatives available, in addition to stone-pine wood. The general efficacy of the Portuguese protective measures towards these two Fagaceae species were never sufficient (one of the oldest determinations for the protection of the oak dated back to the year 1292 [25], and human overexploitation that spanned centuries led to the disappearance of many trees and the decrease of cork- and holm-oak commu- 
nities throughout the country [26,27]. The destructive pressure imposed by shipbuilding was being progressively reinforced by other drivers, such as population growth and the correspondent growth of the need for coal and agricultural expansion [25]. In the end of the fifteenth century the Portuguese territory was virtually woodless, with an attempt to reverse this starting in the eighteenth century, and only with the appreciation of cork did this tendency begin to revert $[25,28]$. The cork-stopper industry, for example, took its first steps in the early 19th century and had a major boost a few decades later [29]; the growth of national cork production was maintained at a constant and homogeneous rate, between 1850 and 1910 [30].

Due to the better capacity for agricultural production compared with the mountainous areas, the Barrocal has been historically the most populated and wealthy of the Algarve's sub-units. Since the middle of the 20th century, cereal production drastically declined in the mountainous and coastal areas. The littoral strip started to become densely populated with the touristic boom of the late 20th century. Today, tourism is the most important economic activity in the Algarve. Nature-conservation sites, belonging to the Natura 2000 network, have spread over the Algarve. It includes five protected areas (two natural parks, one natural reserve and two protected local landscapes) located mainly in the littoral fringe, and two Special Areas of Conservation located in mountain areas.

\subsection{Approach and Analysis Framework}

To produce a long-term time series of the landscape and estimate the long-term trends of change of the forest landscape of the Algarve region, and accomplish the abovementioned study goals, it was necessary to revisit the concepts of scale with its three distinctive dimensions: spatial scale, temporal scale, and organizational hierarchy [31]. Furthermore, it was equally necessary to attain a level of consistency that makes the comparison between historical and recent cartography possible and realistic. Common to other published studies, we found the need for a high degree of insight to extract, on a case-by-case basis, the best information from historical maps, either through guaranteeing the accuracy of their georeferencing, or by the sensible interpretation of the data to be used. The different steps of the process of building a network to fit those different aspects, is detailed in Figure 1.

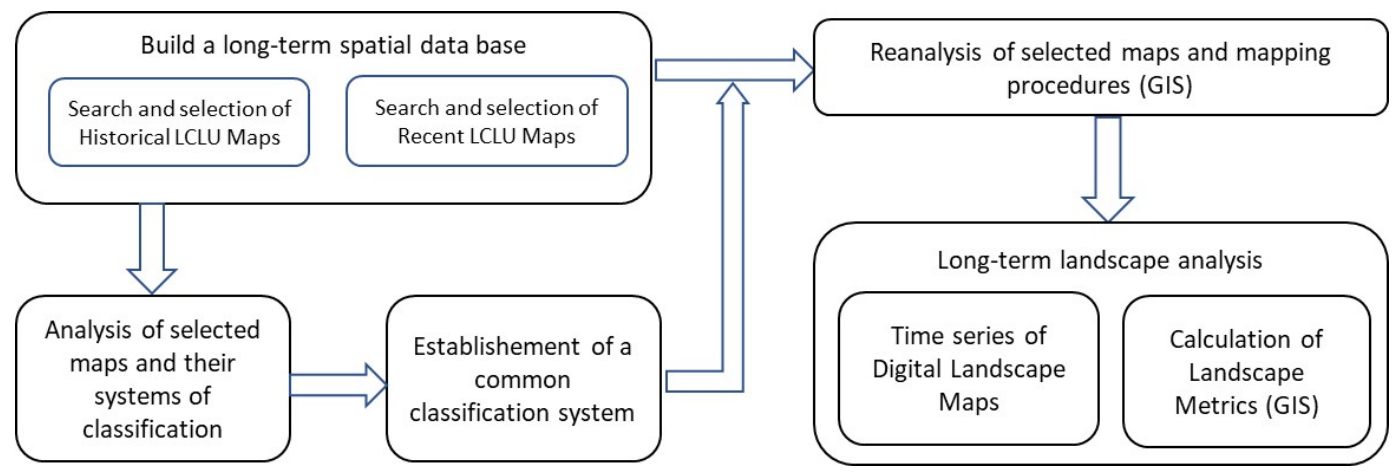

Figure 1. The framework of the analysis.

Accurate and detailed information regarding the historical spatial distribution of cork and round-leaf oaks in Portugal does not exist. The first steps towards producing Portuguese agricultural and forestry cartography were only taken in 1878; the country would, then, initiate the 'in search of exactitude' phase [32]. In 1886 the preparation of the first Portuguese agriculture and forest map (Carta Agrícola e Florestal de Portugal or CAFP) began, from which the first results were published a few years later, at a cartographic scale of 1:50,000 for the South (Algarve and Alentejo regions) and of 1:25,000 for the North of the country [20]. This working plan was considered of 'utmost importance and very notable merit', not only at a national but also European level, as there were no other 
examples of detailed agricultural and forest cartography that spanned vast territories [33]. Unfortunately, the complete set of map sheets was never published and, for a long time, the Algarve gained little from these pioneering initiatives. Despite the thorough and lengthy preparatory field work, the region was only represented in a simplified version of the CAFP, published in 1910, at a cartographic scale of 1:500,000. The chorographic-agricultural drafts, though highly detailed, were never published as 1:50,000 map sheets. Consequently, detailed, and comprehensive cartographic information concerning the Algarve region only became available in the 1950s, after the publication of the second CAFP, provided at a cartographic scale of 1:25,000. In 2018, when the original chorographic-agricultural drafts related to the Algarve were rediscovered, as well as three map sheets that had never been edited, they were found to be well conserved. The subsequent study of these historical documents allowed beginning the rewriting of the history of the distribution of cork and holm oaks in the Algarve in a long-term retrospective, from the 1890s-1900s to the present days. Although, the use of this historical map requires tasks or procedures guaranteeing the accuracy of their georeferencing or the interpretation of the data, and the recreation of new systems of classification that match both the historical and recent data. GIS is an indispensable computer tool materializing the analysis. The opensource geographical information system QGIS (www.qgis.org) was the computational tool used in all procedures that involved the preparation, storage, analysis, calculation or obtaining of cartographic and statistical results from all the spatial information used in the present study.

\subsection{Selected Source Maps}

\subsubsection{Historical Maps}

\section{- $\quad$ Decades of 1890 and 1900}

The 58 chorographic-agricultural drafts complemented by five map sheets comprised the information sources used for the 1890s and 1900s (CAFP 1890-1900s). All material is at a cartographic scale of approximately 1:50,000. Each chorographic-agricultural draft has two versions:

- One, painted with Chinese ink on tracing paper, presents the agricultural and forest crops and the proportions between them when more than one species occurred in the same plot, and, additionally, other information of cadastral value, such as the divisions of the large and medium properties. The plots with agricultural and forest species are represented by polygons, through a sequence of codes in order of dominance of these crops, and the proportions are represented by a corresponding sequence with the relative weights of each crop present in the plot.

- Another, drawn on opaque paper and coloured in pencils, respects a chromatic table of the predominant land cover and use. It was prepared from the original version, to which more details were added, namely roads and paths, buildings, the permanent and seasonal hydrographic network, the largest water bodies, and springs of some importance, as well as the geodesic vertices [34].

The usage of these sources of information demanded a great and lengthy preparation effort. All the chorographic-agricultural drafts and map sheets were: (i) digitized (tiff format, $300 \mathrm{dpi}$ ); (ii) georeferenced and georectified (ETRS89 PT TM06-EPSG:3763) using the geodesic network marked in the drafts and sheets (which still exist today as groundcontrol points); (iii) vectorized with respect to all polygons that mark the occurrence of cork and holm oaks were. We aimed to rigorously replicate all the detail present in the chorographic-agricultural drafts and map sheets. The verification of the absence of geometric and topological errors was done using GIS functionalities. In the attribute table of the shapefile, the appropriate fields were created and filled for the complete recording of all the available information. Both versions of the chorographic-agricultural drafts were consulted and used autonomously. This redundant information was thus employed to minimize or eliminate reading and interpretation errors in the LCLU recorded in the choreographic-agricultural drafts and the unedited map sheets. 


\section{- $\quad$ Decade of 1950}

The source of information used for the 1950s was the second CAFP (CAFP 1950s). The Algarve is represented in 47 map sheets, only available in the conventional way (printed on paper at a cartographic scale of 1:25,000). It was therefore necessary to digitize, georeference, georectify, and polygonally vectorize them, and to fill the fields of the attribute table of the shapefile [21]. The procedures adopted were similar to those described previously for the CAFP 1890-1900s.

The CAFP 1950s classification system is also a non-hierarchical one, complex enough to allow a very detailed description of agricultural and/or forest crops, noting the presence of one, two or more plant species, and also of two strata of vegetation [35]. It consisted in the use of letters (predominantly agricultural or forestry crops), symbols (mixed occupancy, that is, associations or mosaics of cultures, or the presence of scattered trees, predominantly), colour of the letters (different herbaceous and shrub level land cover or lack thereof), and polygon colours (illustrative of the plant species present, in patterns and proportions associated with the relative importance of the different species).

\subsubsection{Recent Maps—Decade of 1990 and 2000}

The more recent sources of information used were the COS-Land-Cover Land-Use Map of Portugal, available free of charge on the Direção-Geral do Território website, in shapefile format, ETRS89 PT TM06 georeferenced. The equivalent cartographic scale of all COS is 1:25,000 [36].

All COS have classification systems with a hierarchical format. The COS 1995 has five hierarchical levels with 89 classes in the most detailed one. Each plot was identified and labelled according to the recommendations established for LCLU classification systems, such as that established for FAO by Di Gregorio and Jansen [37]. A class is assigned whenever it represents an area greater than or equal to $75 \%$ of the polygon in which it is included, regardless of whether there may also be areas for other occupancy, if they represent less than 25\% [38]. COS 2018 had the number of hierarchical levels reduced to four and has only 83 classes. The number of them dedicated to agriculture, pastures, agroforestry areas, forests, and scrub is only $37.3 \%$ of the total number of classes, with the number of classes dedicated to artificial territories being higher and reaching 39.8\% [39].

\subsubsection{Accuracy of the Selected Source Maps}

The accuracy of the four source maps was evaluated, even considering the limitations that exist to assess the accuracy of maps of this nature and characteristics.

For the historical maps (CAFP 1890-1900s and CAFP 1950s), which were digitized, georeferenced, georectified, vectorized and interpreted, the evaluation of the accuracy was focused on the absence of errors introduced during the vectorization and interpretation steps. To do this, 5,000 random points were generated using a feature of QGIS. Afterwards, each point was verified, compared with the information registered in the original maps, in conventional support, and with the vector information, in digital support. After a second round of comparison and corrections, the number of errors (differences between original and vector) was $0 \%$.

The recent maps (COS 1995 and COS 2018), since both are official information produced and published by the official national authority (Direção-Geral do Território), were used in this study without any assessment of their accuracy beyond the official one. The COS 1995 final report states its overall accuracy to within an error of 3\%, for a confidence level of 79\% [40]. Until now, Direção-Geral do Território had not disclosed any results of the COS 2018 accuracy assessment.

\subsection{Classification System for Cork and Holm Oaks' Land Cover and Land Use in the Algarve}

Research on LCLU changes over time is one of the most challenging subjects faced when a time series of thematic cartography is available for analysis. To be able to accomplish this task, it is essential to ensure, between each and among all selected maps, 
a sufficient consistency in the description of LCLU. That includes thematic resolution, also called class resolution, and categorical or thematic scale, or the level of detail at which a variable is thematically defined [38]. Beyond the required consistency between the different classification systems, similarities between minimum mapping areas and minimum mapping distances between lines, as well as the accuracy in the acquisition of thematic information, whether carried out through field surveys or by remote detection, are fundamental requirements to keep in mind.

Between the CAFP 1890-1900s, the CAFP 1950s, and the COS 1995 and 2018, there are several heterogeneities. The two CAFPs adopted non-hierarchical classification structures, while the three COSs adopted hierarchical classification structures. Non-hierarchical systems are better able to describe all the complexity of LCLU, particularly when the scales of representation are detailed. However, they often require a much greater effort when it is necessary to adapt them to a hierarchical system, and sometimes grave doubts arise that are difficult to resolve. Hierarchical classification systems can better describe the dominant patterns of LCLU, regardless of the geographic scales and sources of information themselves [38]. Additionally, the two CAFPs have classifications very oriented to agriculture and forests, while the two COSs have multipurpose classifications, in which the diversity of artificial surfaces is generally represented in more detail than in the agricultural, agroforestry, forest, and semi-natural territories.

The classification system and the legend that were built to make possible the study of the present spatial time series have a two-levelled hierarchical format (Table 1). Although not being as detailed as desired, it aims at making the best use of the heterogeneity existing in the different legends that were adopted from the four map sources used. For each of the oak species under analysis, two classes are marked at the top hierarchical level, and a total of six classes are marked at the most detailed hierarchical level, although one class is common to both species (Agroforestry lands -AFL—with cork and holm oaks). This legend, which is focused on only two species, is comparable with the official legend of the LCLU currently adopted for Portugal (COS 2018), with one being of CORINE Land Cover, and with others classification systems or studies on LCLU changes and environmental impacts $[37,39,41-43]$.

Table 1. Proposed classification system for cork and holm oaks in the Algarve and correspondent land-cover-land-use classifications in the source maps.

\begin{tabular}{|c|c|c|}
\hline Species & Land Use-Cover Type & Cover-Vegetation Type \\
\hline \multirow[b]{2}{*}{$\begin{array}{c}\text { Cork oak } \\
\text { (Quercus suber) }\end{array}$} & $\begin{array}{l}\text { agroforestry lands (AFL) with } \\
\text { cork oak }\end{array}$ & $\begin{array}{l}\text { agriculture, possibly also with semi-natural areas, with cork-oak } \\
\text { agriculture, possibly also with semi-natural areas, with cork and } \\
\text { holm oaks }\end{array}$ \\
\hline & cork-oak forests & $\begin{array}{l}\text { cork-oak forests (sobreiral) } \\
\text { cork oak in forests with other broadleaf and/or coniferous trees } \\
\text { open cork-oak forests, possibly also with other forest species } \\
\text { non-dominant cork oak in forests with other broadleaf and/or } \\
\text { coniferous trees }\end{array}$ \\
\hline \multirow[b]{2}{*}{$\begin{array}{l}\text { Holm oak } \\
\text { (Q. rotundifolia) }\end{array}$} & $\begin{array}{l}\text { agroforestry lands (AFL) with } \\
\text { holm oaks }\end{array}$ & $\begin{array}{c}\text { agriculture, possibly also with semi-natural areas, with holm-oak } \\
\text { agriculture, possibly also with semi-natural areas, with cork and } \\
\text { holm oaks }\end{array}$ \\
\hline & holm-oak forests & $\begin{array}{l}\text { holm-oak forests (azinhal) } \\
\text { holm oaks in forests with other broadleaf and/or coniferous trees } \\
\text { open holm-oak forests, possibly also with other forest species } \\
\text { non-dominant holm oaks in forest with other broadleaf and/or } \\
\text { coniferous trees }\end{array}$ \\
\hline
\end{tabular}

This system of classification allowed us to map and quantify Fagaceae occurrence by species (cork oak and holm oak), and by type of land cover, i.e., the natural habitats in forest patches (subcategories in the group designed forest patches) and the seminatural 
habitats in agroforestry areas (subcategories in the group designed AFL patches). In the AFL classes, agriculture was considered as both temporary crops, namely cereals and vegetables, and permanent crops, such as orchards, vineyards, and olive groves. Therefore, the mapped cork- and holm-oak patches represent every area of the regional landscape with a tree-based community, whether natural or semi-natural, in which cork oak and/or holm oak occur, whether they are the dominant species in the community or a nondominant species.

The minimum mapping area (MMA), a scale-dependent cartographic concept, is a criterion that began to be objectively applied in COS only after the value of one hectare $\left(0.01 \mathrm{~km}^{2}\right)$ was adopted. For the two CAFPs, this criterion does not exist, but the analysis of the polygon areas shows that MMA on both historical maps used are significantly smaller than those of the COS maps. The criterion applicable to the study of the present time series of cartographic maps can then be adopted, as that MMA is, at most, of $0.01 \mathrm{~km}^{2}$.

\subsection{Landscape Metrics}

Many connectivity metrics have been used to assess the connectivity of a landscape and to evaluate the effects of land-use changes [7]. Despite disagreements among academics on the measurements of connectivity relying on data-dependent framework metrics, the structural connectivity metrics usually considered are the: spatial pattern indices, such as size, extent, shape; distance between patches; grid-based occurrence data, to quantifying species' spatial occurrences; and buffer radius and incidence function [44].

Spatial pattern indices are spatially explicit habitat data quantifying the number, size, extent, shape, and/or aspects of the spatial arrangement of landscape elements. Used as connectivity metrics, they rely on the assumption that spatial patterns affect species' movement through the landscape. The total number of patches, patch area, and patch perimeter, among others, are examples of spatial pattern metrics [44]. We also calculated the total area covered by oak patches to quantify the dimensions of their distribution over the entire region.

Between-patch distance metrics pretend to measure inter-patch connectivity, i.e., the connectivity between different habitat patches in the landscape. The nearest neighbour distance (NND) refers to the interpatch distance and measures the distance to the nearest occupied patch. Technically, it represents a patch-isolation measure, connectivity being its inverse. It provides a simple, patch-level structural connectivity metric [44].

Grid-based occurrence data quantify species' spatial occurrences at a landscape level, derived by dividing the landscape into a series of equal sized grid cells and registering the presence or absence of the target species in each cell [44]. We quantified the occurrence, i.e., the presence of the target species (cork-oak and holm-oak patches) in cells, as well as the number of patches per cell. Both pretend to quantify the regional pattern of distribution of the species-the regional extent (number of cells occupied) and dispersion pattern (number of patches per cell).

With QGIS, the calculation of each polygon's properties, and the statistical analysis per type or class of polygons were performed for each year in the analysis. Eight landscape metrics were calculated for each category of landscape patch with cork oak and/or holm oak-Table 2.

Table 2. The landscape metrics calculated for each category of landscapes patch with cork oak and/or holm oak.

\begin{tabular}{cccc}
\hline Initials & Designation & Units & Meaning \\
NP & number of patches & number & $\begin{array}{c}\text { The total number of oak } \\
\text { patches in the regional } \\
\text { landscape }\end{array}$ \\
\hline PA & patch area & $\mathrm{km}^{2}$ & The average oak patch area \\
\hline PTA & patch total area & $\mathrm{km}^{2}$ & $\begin{array}{c}\text { The sum of the oak patch } \\
\text { areas }\end{array}$ \\
\hline
\end{tabular}


Table 2. Cont.

\begin{tabular}{|c|c|c|c|}
\hline Initials & Designation & Units & Meaning \\
\hline PP & patch perimeter & $\mathrm{km}$ & $\begin{array}{c}\text { The average oak patch } \\
\text { perimeter }\end{array}$ \\
\hline IPD & inter-patches distance & $\mathrm{km}$ & $\begin{array}{c}\text { The average linear distance } \\
\text { between the geometric centers } \\
\text { of two nearest neighbor } \\
\text { patches }\end{array}$ \\
\hline PD & $\begin{array}{l}\text { patch distribution across the } \\
\text { landscape }\end{array}$ & number & $\begin{array}{c}\text { The number of } 100 \mathrm{~km}^{2} \text { grid } \\
\text { squares from the regional } \\
\text { landscape with oaks patches } \\
100\end{array}$ \\
\hline PCN & patch density & number/grid & $\begin{array}{l}\text { The average number of oak } \\
\text { patches per } \\
\text { occupied } \mathrm{km}^{2} \text { grid squares }\end{array}$ \\
\hline PCA & patch clustering & $\mathrm{km}^{2} /$ grid & $\begin{array}{c}\text { The average of the total area } \\
\text { cover by oak patches per } \\
\text { occupied } 100 \mathrm{~km}^{2} \text { grid } \\
\text { squares }\end{array}$ \\
\hline
\end{tabular}

\section{Results and Discussion}

Changes in total area of occurrence of the cork and holm oaks in the regional landscape of the Algarve is firstly described in detail, to get an overview of the dimension of spatial distribution of each species over time and across the region. Further, results of the other metrics are presented in a less disaggregated mode to complete the description of the connectivity changes over time.

In the Algarve, the total area covered by patches of the native cork oak and holm oak grew between the 1890-1900s and the end of the 20th century, after which they remain almost unchanged. In the turn of the 19th to the 20th century, the distribution of cork and holm oaks in the Algarve was recognized as being very small and it was considered that it would be of high regional interest to promote its expansion [45-47]. The present results, obtained by extending the analysis back in time, confirms that, 120 years ago, cork oak occurred in only $5.2 \%$ of the Algarve and holm oak in only $3.4 \%$, and that the cork oak had its area multiplied by about 3 times and the holm oak by 1.5 times during this period-Table 3 and Figures 2-6.

The expansion of the oaks is evident during the period under analysis, especially concerning the cork oak during the 20th century. Between the 1890s-1900's and the 1950s the total cork-oak area almost doubled (cork-oak forest patches by increased 1.87 times, and AFL with cork and holm oaks 2.2 times). The total area of holm oak slightly increased (1.2 times) - the decrease in the holm-oak forest patches being compensated for by the growth of AFL patches with holm oak and cork oak (Table 3; Figures 2, 3 and 6).

From the 1950s to the end of the 20th century (Table 3; Figures 3, 4 and 6) corkoak expansion continued, and the area of holm oak shared a similar pattern of change. The cork-oak area increased by 1.5 times, with forests patches almost doubling and AFL patches decreasing 2.5 times. The holm oak patches' total area grew 1.4 times, with forests increasing 2.6 times, while AFL decreased 2 times. During the 21 st century the total area of cork oak was almost unchanged, with a very slight increase in forests patches and a decrease in AFL. The total area of holm oak slightly decreased (1.1 times). During the 20th century, the area of cork oak increased at a rate of more than $50 \mathrm{~km}^{2} /$ decade, and in the 21st century the rate increase reduced to $5 \mathrm{~km}^{2} /$ decade. The area of holm oak increased at a rate of more than $10 \mathrm{~km}^{2} /$ decade during the 20 th century and, after that, decreased at a rate of almost $10 \mathrm{~km}^{2} /$ decade (Table 3; Figures 4-6). 


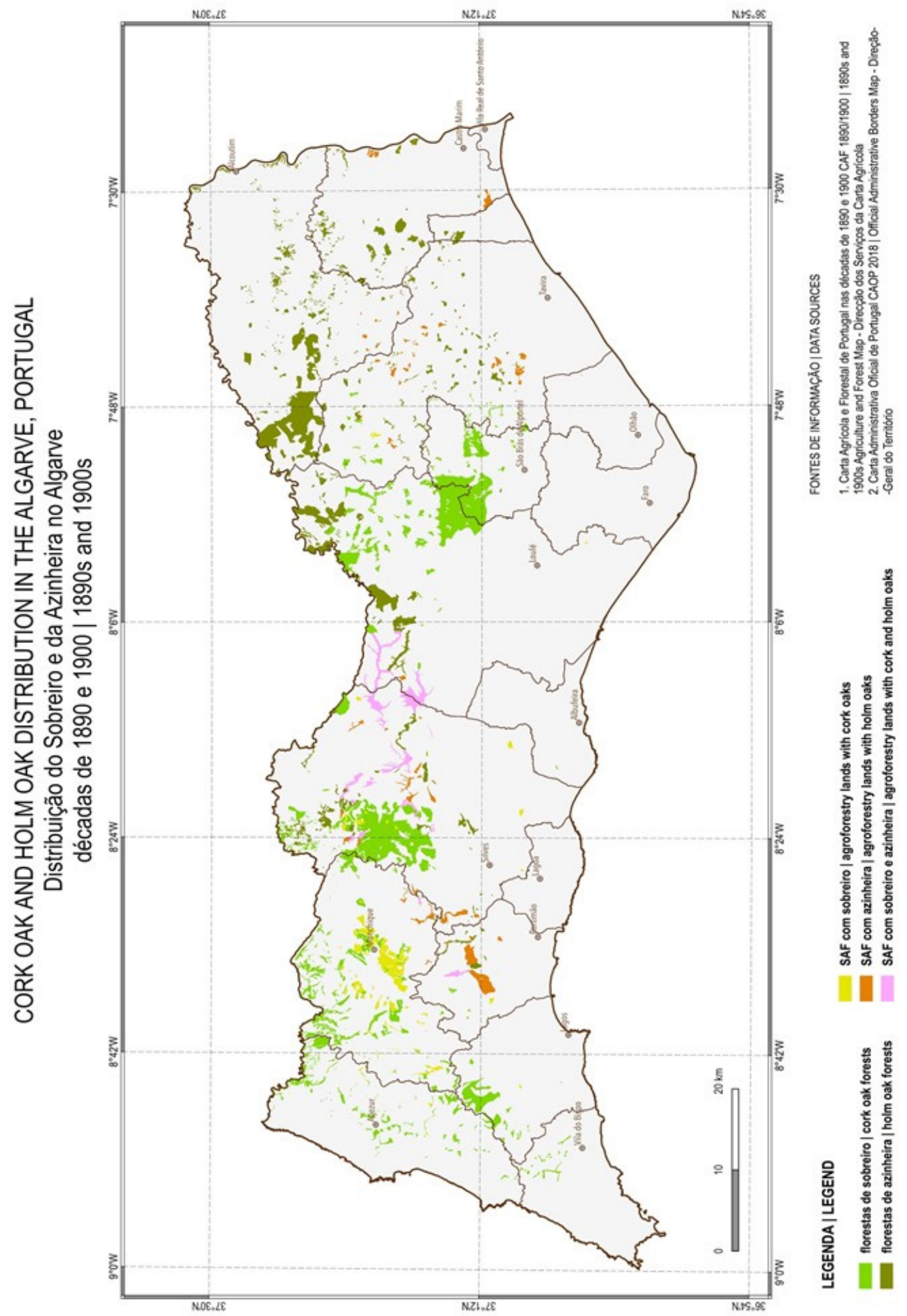

Figure 2. Cork oak and holm oak distribution in the Algarve, Portugal, at the turn of the nineteenth century. 


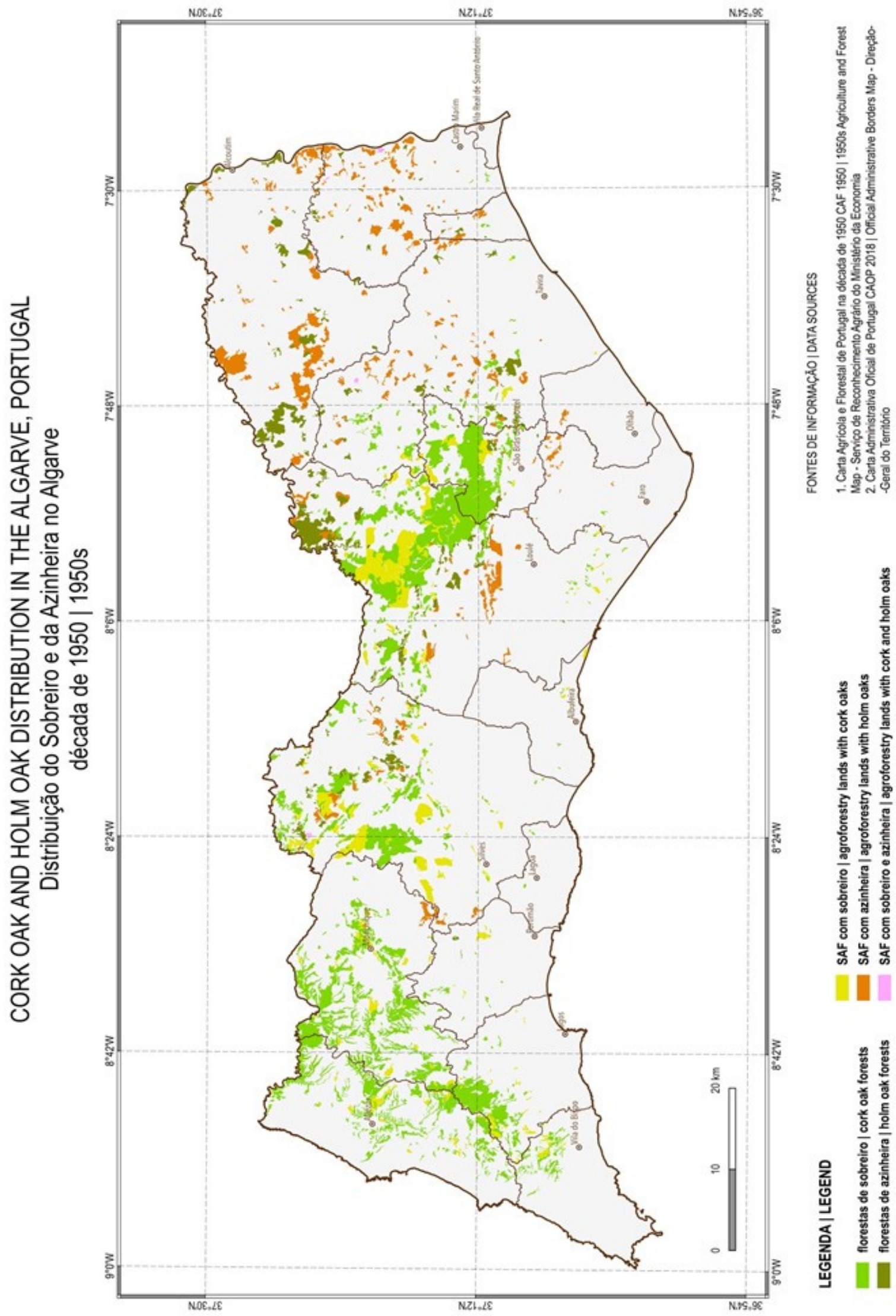

Figure 3. Cork oak and holm oak distribution in the Algarve, Portugal, in the 1950s. 


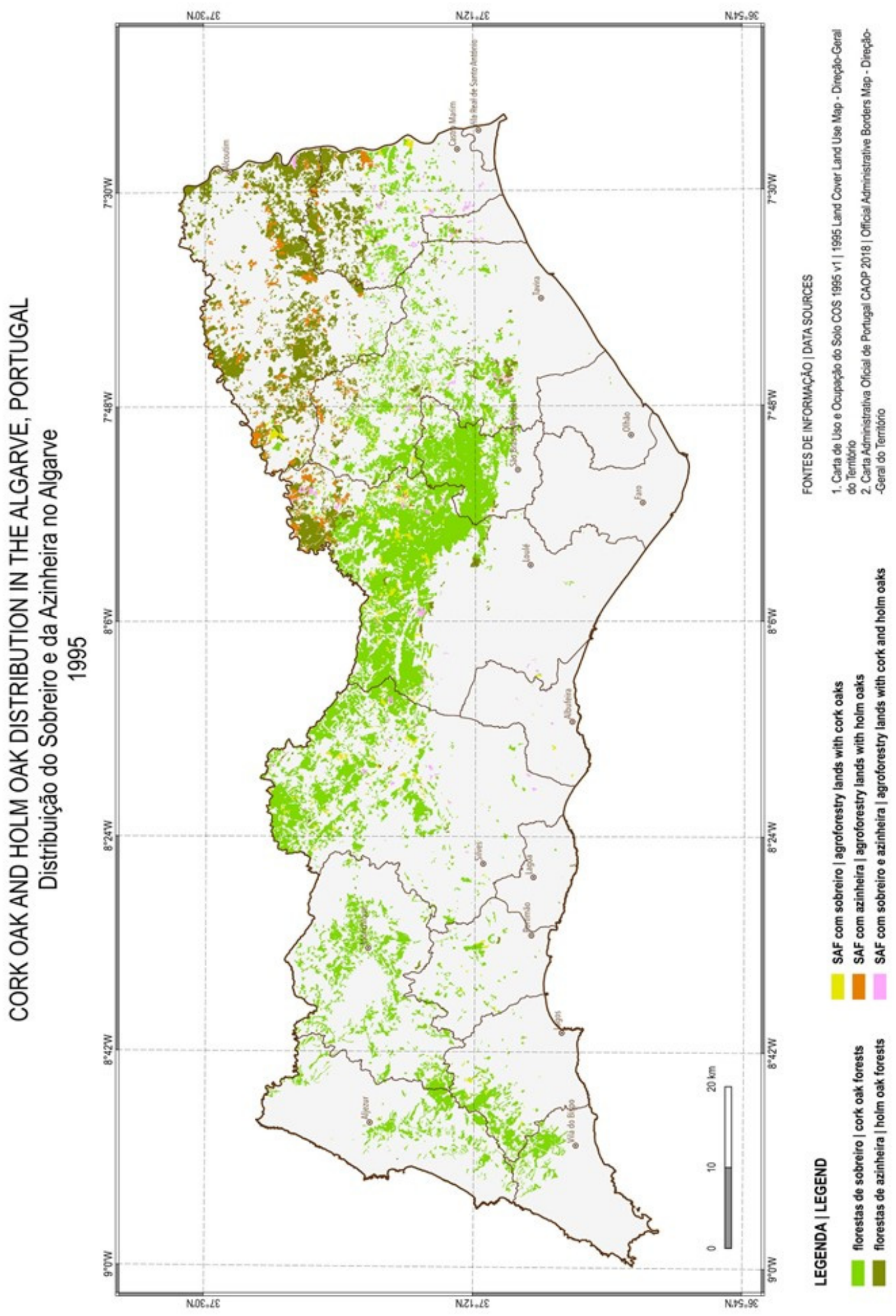

Figure 4. Cork oak and holm oak distribution in the Algarve, Portugal, in 1995. 


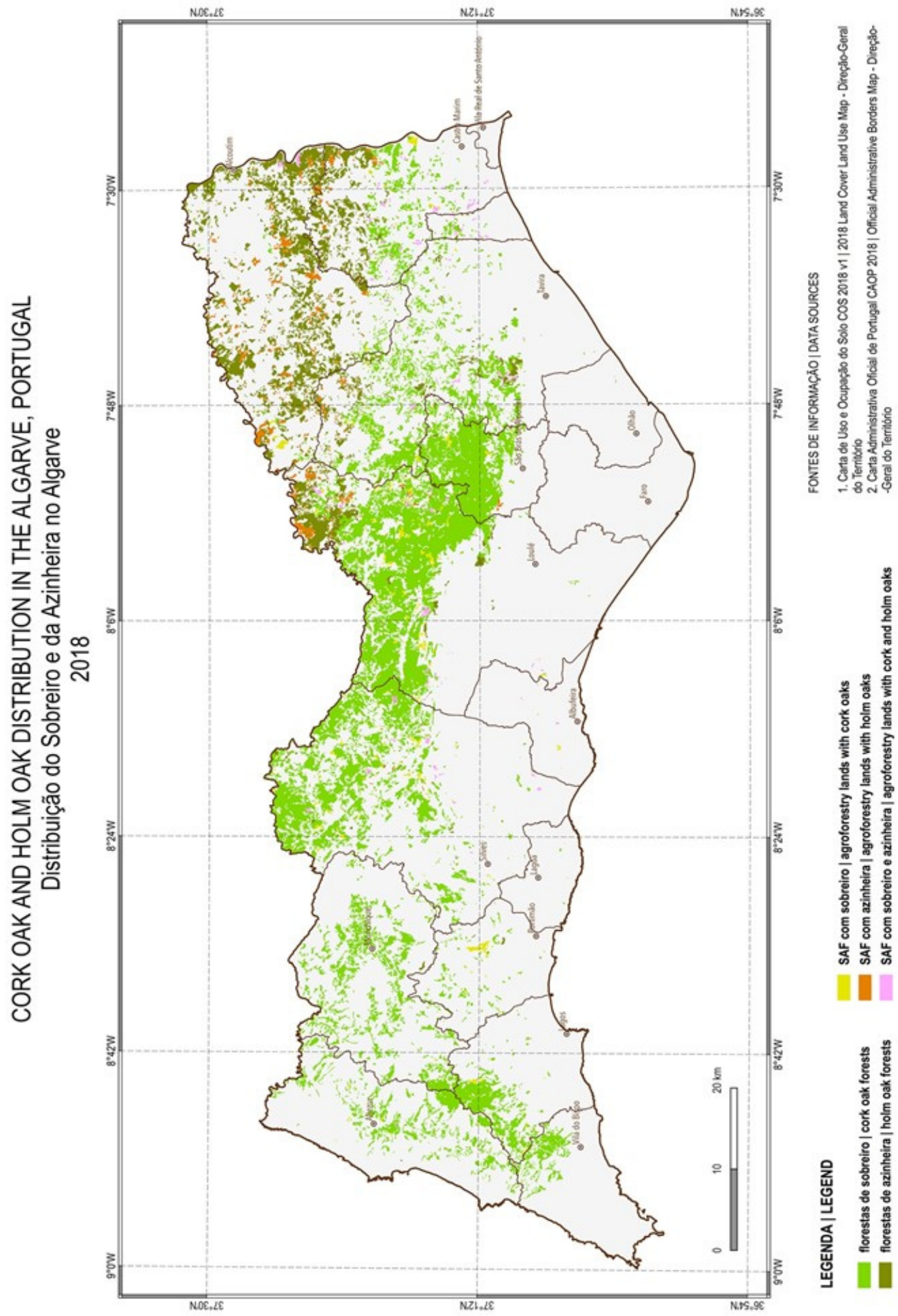

Figure 5. Cork oak and holm oak distribution in the Algarve, Portugal, in 2018.

Over the entire studied period, cork oak was always the species with the greatest spatial distribution in the region. The holm oak, which initially occupied the second position, was losing importance and was surpassed in the hierarchy by stone pine and eucalyptus [47]. The particularly sharp growths in AFL (increasing until the 1950s, followed by a decrease) would be related to the Portuguese governmental wheat campaign (Campanha do 
Trigo; 1929-1938) which had promoted the strong growth of cereals cultivation in the South of Portugal; in the Algarve, it had reached its peak in the early 1960s [48-51]. In southern Portugal, the complementarity between the production of cereals and the production of cork was such that development of the first encouraged the growth of the second [29]. In the Algarve, this hypothesis may also be valid, as small and medium-sized rural properties dominated and there were no strong public policies geared to the agroforestry sector during historical times. In this way, the contribution to family economies resulting from cork could have been relevant given the modest revenues guaranteed by cereals and livestock. There were several cork processing industries in the Algarve, contributing to the usage of locally produced cork and encouraging rural owners to plant and care for more cork-oak trees and cork-oak stands.

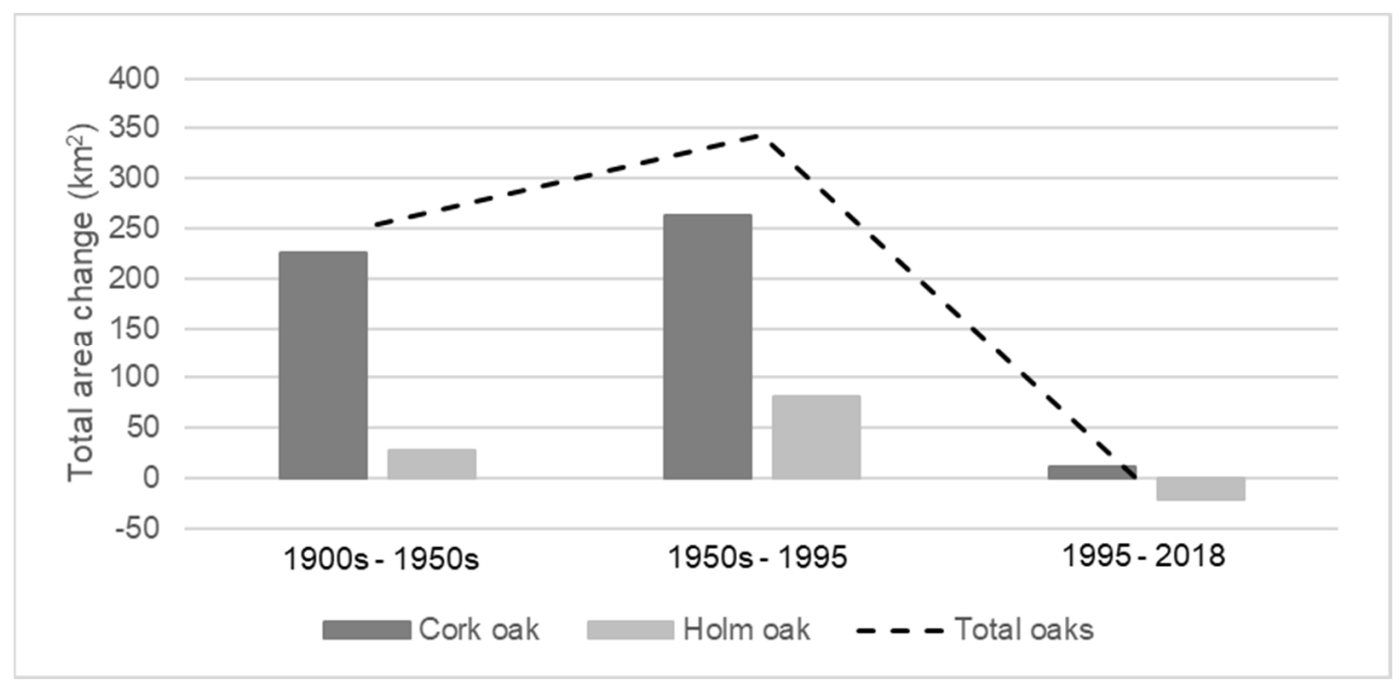

Figure 6. Cork-oak and holm-oak patches' total area change $\left(\mathrm{km}^{2}\right)$ over the studied periods.

Table 3. Total areas of patches with Fagaceae in the Algarve region between 1890-1900s and 2018, by species and by forest and agroforestry patch types (areas in $\mathrm{km}^{2}$ ).

\begin{tabular}{ccccc}
\hline & 1890s-1900s & 1950s & 1995 & 2018 \\
\hline Cork oak (Q. suber): Total & 259.95 & 485.62 & 748.41 & 760.22 \\
Cork-oak forests & 211.18 & 379.17 & 705.70 & 721.66 \\
Cork-oak forests & 74.40 & 234.05 & 662.91 & 721.66 \\
Open & 2.80 & 71.80 & & \\
with other broadleaf and/or coniferous & 120.52 & 24.50 & 42.79 & \\
Not dominant & 13.46 & 48.81 & & \\
Agroforestry Lands with cork oak & 48.77 & 106.45 & 42.71 & 38.56 \\
AFL with cork oak & 25.00 & 105.20 & 28.30 & 24.30 \\
AFL with cork and holm oaks & 23.77 & 1.25 & 14.41 & 14.27 \\
Holm oak (Q. rotundifolia): Total & 169.33 & 196.96 & 277.75 & 256.82 \\
Holm-oak forests & 121.60 & 84.39 & 222.10 & 207.64 \\
Holm-oak forests & 98.62 & 65.25 & 215.83 & 207.64 \\
with other broadleaf and/or coniferous & 7.81 & 2.37 & & \\
Open & 7.71 & 0.65 & 6.27 & \\
Not dominant & 7.46 & 16.11 & & \\
Agroforestry Lands with holm oak & 47.73 & 112.58 & 55.66 & 49.17 \\
AFL with holm oak & 23.96 & 111.32 & 41.25 & 34.91 \\
AFL with cork and holm oaks & 23.77 & 1.25 & 14.41 & 14.27 \\
\hline
\end{tabular}

According to descriptive historical information, the overexploitation of cork and holm oaks spanned centuries in the region, related to cattle, cork-oak exploration for its bark and cork, wood for energy production, and for construction (intensive logging caused 
by Portuguese maritime expansion). There was a general inefficacy of the Portuguese protective measures towards these two Fagaceae species for centuries [25]. Even along with population and agricultural expansion [25], the attempt to reverse this situation started in the eighteenth century and continued in the 19th century with the growing appreciation of cork; afforestation processes in the region become relevant during the first half of the 20th century mainly in mountain areas and continued with the implementation European politics later in the century $(1980 \mathrm{~s}-90 \mathrm{~s})[25,28]$. The quantitative results obtained in the present long-term analysis confirm this.

As Fagaceae species expanded during the first half of the 20th century, the number of oak patches in the regional landscape also increased, mainly during the second half of the century (about a four-fold increase). A decrease in the number of patches has been registered since the end of the 20th century, although, over the entire period of analysis, the number of patches in the regional landscape had increased by about three times (Table 4; Figure 7A). Average patch size and perimeter showed a more irregular pattern of change during the 120 years under analysis, and was similar for both species: increasing during the first half of the 20th century, decreasing during the second half (the average size of the patches halved), followed by a slight increase in recent decades. Despite the decrease in average patch size registered during the second half of the 20th century, the total area covered by oaks maintained the increasing pattern over the 20th century due to the great increase in patch number across the landscape. From 1890-1900s to 1995, oaks become more distributed across the regional landscape (the number of $100-\mathrm{km}^{2}$ grid cells with oak patches increased by $20 \%$ ) and more aggregated (three-fold increase in the number of patches per occupied cell and a two-fold increase in total area covered by oaks per $\mathrm{km}^{2}$ of the occupied cells). After the end of the 20th century the values of these metrics remained almost unchanged. Inversely, average inter-patch distance halved from the 1950s to the end of the century and had a slight increase (by 1.1 times) in 21st century (Table 4; Figure 7B).

Table 4. Cork-oak and holm-oak patch-metrics results (total forest and agroforestry patches) in the regional landscape of the Algarve, between 1890-1900's and 2018.

\begin{tabular}{|c|c|c|c|c|c|}
\hline Species & Metrics & 1900s & 1950s & 1995 & 2018 \\
\hline \multirow[t]{8}{*}{ Cork oak } & NP (number of patches) & 596 & 901 & 2761 & 2279 \\
\hline & PA (patch average area, $\mathrm{km}^{2}$ ) & 0.44 & 0.54 & 0.27 & 0.33 \\
\hline & PTA (patch total area, $\mathrm{km}^{2}$ ) & 259.95 & 485.64 & 748.41 & 760.22 \\
\hline & PP (patch average perimeter, $\mathrm{km}$ ) & 3.35 & 4.69 & 2.85 & 3.28 \\
\hline & IPD (interpaches average distance, $\mathrm{km}$ ) & 0.91 & 0.83 & 0.50 & 0.57 \\
\hline & PD (number of $100 \mathrm{~km}^{2}$ grid squares with cork oak) & 38 & 51 & 60 & 62 \\
\hline & PCN (average number cork oak patches/grid square) & 17.9 & 20.8 & 50.9 & 41.1 \\
\hline & PCA (average total cork oak area $\mathrm{km}^{2} /$ grid square) & 6.84 & 9.52 & 12.47 & 12.26 \\
\hline \multirow[t]{8}{*}{ Holm oak } & NP (number of patches) & 627 & 467 & 1748 & 1265 \\
\hline & PA (patch average area, $\mathrm{km}^{2}$ ) & 0.27 & 0.42 & 0.16 & 0.20 \\
\hline & PTA (patch total area, $\mathrm{km}^{2}$ ) & 169.33 & 196.97 & 277.75 & 256.82 \\
\hline & PP (patch average perimeter, $\mathrm{km}$ ) & 2.33 & 3.66 & 2.19 & 2.61 \\
\hline & IPD (interpaches average distance, $\mathrm{km}$ ) & 0.73 & 1.06 & 0.47 & 0.58 \\
\hline & PD (number of $100 \mathrm{~km}^{2}$ grid squares with holm oak) & 42 & 41 & 46 & 44 \\
\hline & PCN (average number holm oak patches/grid square) & 16.7 & 13.5 & 41.7 & 31.5 \\
\hline & PCA (average total holm oak area $\mathrm{km}^{2} /$ grid square) & 4.03 & 4.80 & 6.04 & 5.84 \\
\hline
\end{tabular}

The results, all together, reveal an increasing connectivity pattern among patches with native oak species during the studied period. The increase occurred over the last century, and, afterward, connectivity has remained almost unchanged. During the 20th century, changes in the number of patches and average patch size had led to a progressive increase of the distribution (total area) and in the aggregation or closeness of oaks patches, reducing the distance among patches. As has been considered for other forests [52], organisms highly specialized in forest habitats and/or with lower dispersal distances tend to be most affected by habitat-patch size and by their isolation in non-habitat matrices [2,53]. An 
arbitrary distance of about $750 \mathrm{~m}$ around patches could be considered the range for the movement between habitat patches for the high-mobility seed dispersers [44]. Therefore, in the case of the Algarve regional landscape, the decrease observed during the last century in inter-patch distance to around $500 \mathrm{~m}$ suggests that the recent higher proximity among patches should not be enough to assure the mobility of pollen dispersers (e.g., insects) and the low-mobility seed dispersers (e.g., small birds) between oak habitat patches in the regional landscape. We should state that the increase registered in landscape connectivity during the 20th century, although relevant, has not reach a satisfying level, and further increase is necessary to facilitate the movement of animals. A reflection on politics that could reverse the stagnation observed during the last decades is urged.
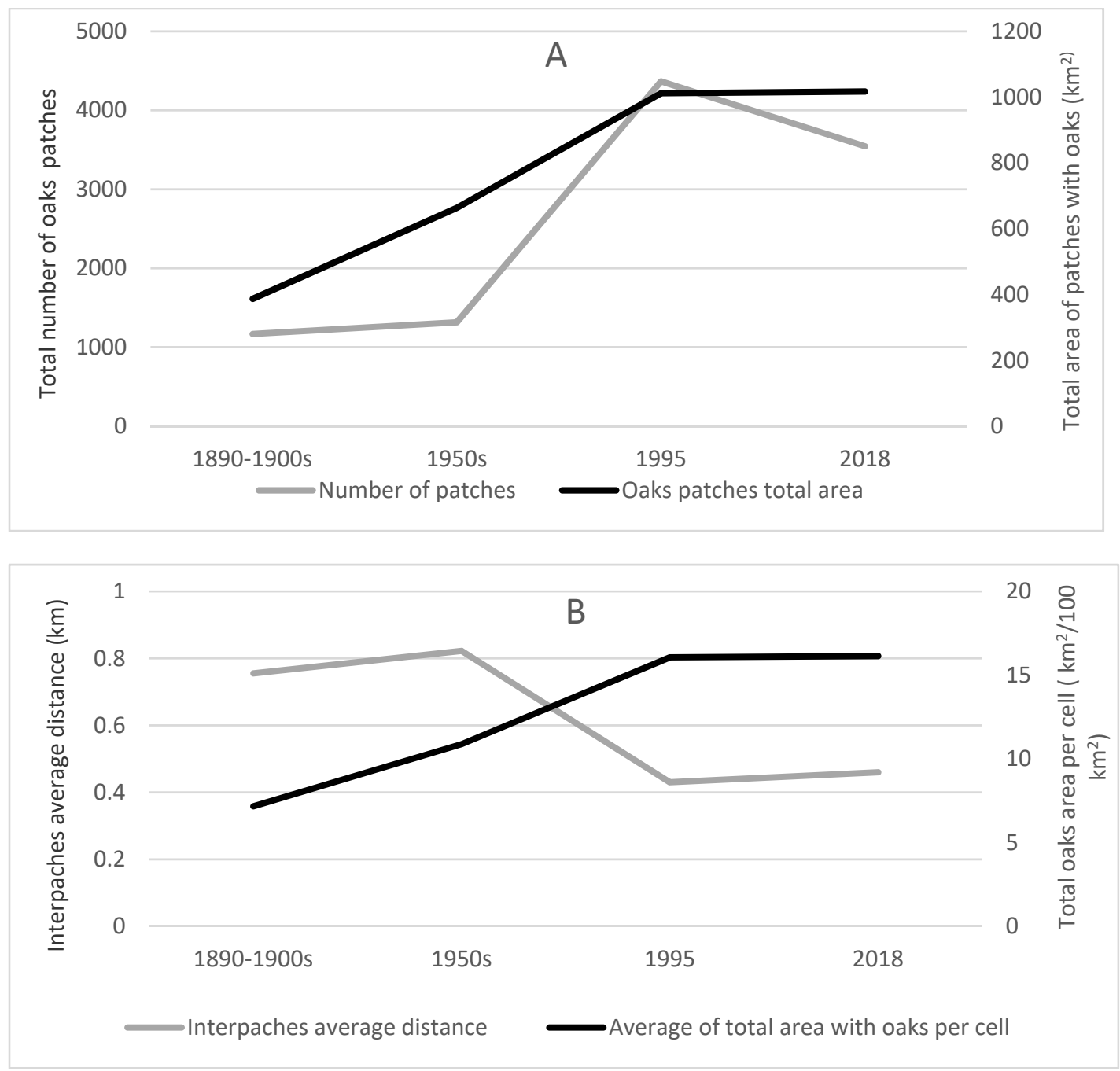

Figure 7. Oak-patch (total Fagaceae) metrics change between the 1890-1900's and 2018 in the regional landscape of the Algarve: (A) total number of oak patches and total area cover by oak patches; (B) interpatch average distance and average area of oaks per $100 \mathrm{~km}^{2}$.

Metrics that only measure between-patch or inter-patch connectivity can produce misleading results, because these only account for the emigratory and immigratory movements between patches. The inclusion of within-patch or intra-patch connectivity measure, that accounts for the movements of animals within the habitat patch is important for accurate results [7]. Nearest neighbor distance metrics have been found to perform poorly in assessing connectivity, as they are more sensitive to sample size than other, more complex, connectivity metrics [54]. In future developments, an integration of inter-patches and 
intra-patch connectivity measures will be explored. Functional connectivity measures, such as buffers, if applied to the oak patches, also will complement the picture of the connectivity of terrestrial landscape of the Algarve region. A list of essential variables with which biodiversity can be monitored from space has been already defined [55]. Remote sensing potentialities will be explored in future developments.

The human overexploitation of cork oak and holm oak spanned centuries in Portuguese territory and began reversing in the 18th century. The present results revealed that the trend, started more than 200 years ago, had persisted until the end of the 20th century and then stabilized in the 21st century. The present long-term analysis showed that the expansion of the areas occupied by native oak species has increased in connectivity, although the closeness among oaks patches seems only to allow the movement of high-mobility seed dispersers over the landscape. These insights about the long-term changes in the distribution and connectivity of native tree species in the region could be considered the main contribution of the present study. A reflection on the effects of the more recent politics on forest land use, and their consequences for the promotion of regional biodiversity, is needed, when they are viewed within such a broader, retrospective time span.

Although the network proposed showed to be a valuable tool for the analysis of long-term changes of landscape qualities, when applied to the Algarve region, besides the apparent clear results presented, there are some limitations associated with the key discontinuity that breaks the entire series. The two historical sources of information are agricultural and forest maps with complex legends, able to represent in detail the species that had existed by adopting non-hierarchical classification systems. The three recent source maps are multipurpose cartographies, and, consequently, are less concerned with meticulous rigor in the representation of all the extant agricultural and forest species at the time, representing only the dominant(s) species, and had adopted systems of hierarchical classification. It is a change in the hierarchical classification structure (organizational hierarchy) that is insuperable, unless all recent data sources were revisited, and maps redone. Therefore, it was necessary to assume as limitations: (i) the COS did not count the classes 'nondominant cork oak in forests with other broadleaf and/or coniferous trees' and 'nondominant holm oaks in forests with other broadleaf and/or coniferous trees'; (ii) it was not possible to calculate the real areas of each species, figures that would certainly be closer to the truth than the respective total area; and (iii) the analysis could not be done at the hierarchical level of highest resolution and had to remain at the top hierarchical level. So, our analysis is limited to a small thematic resolution and, therefore, the results are not as complete as they would have been otherwise intended [56]. On the other hand, accurate observation of the recent maps (1995 and 2018) pointed to the existence of a heterogeneity in the attribution of the classes most suited to the LCLU of the plots where cork and holm oaks occurr. Particularly regarding holm oak, there are unjustifiable variations between agroforestry lands with holm oaks and holm-oak forests. In 1995 and 2018, the AFL with holm oaks represented about $20 \%$ of the total area with holm oaks. For cork oak these fluctuations also occur, although with less contrast (around 5\% in 1995 and 2018). It should be noted that these deficiencies have already been recognized by the Direção-Geral do Território, who have pledged to review all COS prior to 2018 and adopt, as the single official legend for LCLU, the one established for 2018. Such procedure will make comparability between the different COSs much more robust, but it will significantly reduce the usefulness of these cartographies for research on agriculture, forest, and agroforestry land-cover-land-use changes over time in Portugal, since the classification is insufficiently disaggregated. In the Algarve, the magnitude of growth in areas occupied with cork and holm oaks between the first available historical map and the most recent one is so robust that it is completely undeniable that there has been expansion in the distributions of the two species throughout the 20th century. It will be difficult to deepen the knowledge presented in this study, regarding to the distributions of the two species in the Algarve, as the sources have been explored in an exhaustive way. Future challenges will focus on extending the methodology to other classes of LCLU. 
The system of classification adopted allowed the quantification of Fagaceae patches' occurrence in the regional landscape and their proprieties by species (cork oak and holm oak), and by level of naturalization (natural habitats in forest patches and the seminatural habitats in agroforestry areas), across a long period of time. Yet, the fact that the cork- and holm-oak patches mapped represent every area of the regional landscape with a tree-based community in which individuals of one or both oaks occur whether as dominant species in the community or as nondominant species, is, for us, a controversial assumption of the classification system adopted. On the one hand, this assumption seems to introduce an overrating of the real spatial distribution of the species. On the other hand, it is commonly considered that other types of tree-related covers also play an important role in the connectivity of terrestrial ecosystems and, consequently in regional biodiversity conservation. Areas of the landscape with native Pinus species-related communities, Mediterranean scrubland communities, and even traditional dry orchards should facilitate the movement of animal species across the regional landscape and therefore play a role in landscape connectivity and the preservation of regional biodiversity-and, those are the cover-dominant types in the lands where cork and holm oaks appear as nondominant species, where they have been considered as oak-patch areas in the present study. Another aspect, reinforcing this other side of the controversy, is the fact that, to express the importance of it natural value, any individual of both species in this analysis is protected under Portuguese law. Thus, if one focuses on the change over time of the amounts and arrangements of habitats in the regional landscape and returns to the original concept of landscape connectivity, the potential influence of habitat change on the movement of animals become evident. In the Algarve region, the increase in the total area of Fagaceae species occurrence, in mean area of patches and their number, suggests a structural connectivity increase over time and, therefore, a promotion of the movement of species across the landscape. Moreover, and because the inter-patch space matters, in this regional landscape other tree and scrub-based communities occur often in the rural areas where Fagaceae patches are mostly distributed, and this should be considered to guarantee a low degree of barrier effect in the inter-patch space, or to facilitate the movement of animals between patches. Therefore, real landscape connectivity may be higher than metrics revealed.

Concerning the accuracy of the four source maps, validation of the CAFP 1890-1900s through cross-validation procedures is almost impossible, as all the original chorographicagricultural drafts were based on field surveys. For the CAFP 1950s, COS 1995, and COS 2018, some cross-validation procedures could be adopted [56], namely through the analysis of orthophotographies from the same or close dates. However, the official national authority that owns these orthophotos does not make them available, even for research. Therefore, it was not possible for us to carry out any cross-validation and, as a result, to assess CAFP 1950s, COS 1995 and COS 2018 accuracy.

Deforestation has been considered one of the main threats to biodiversity, increasing forest fragmentation and reducing landscape connectivity [1-3]. In the Algarve region, deforestation has spanned centuries, but native oaks' afforestation processes have introduced relevant changes in regional landscape connectivity since, at least, the end of the 19th century. However, the promotion of landscape connectivity in the region is still a challenge because the level of closeness between patches does not already ensure the movement of different groups of animals over the landscape. In the future, the focus on the forest recovery process of native tree species remains a fundamental question concerning biodiversity conservation in the Algarve.

\section{Conclusions}

In the Algarve, the period of greatest expansion of the native species of cork and holm oaks occurred during the 20th century. Since the end of the 20th century, the total area has remained practically unchanged. The expansion of the native oaks reduced the distance between oak patches in the regional landscape and increased connectivity. Although, this greater recent closeness between oak patches only seems to allow the inter- 
patch movement of high-mobility animals. The insights about the long-term change in the connectivity of native oak-related communities in the Algarve suggest that the promotion of regional landscape connectivity is still necessary and a reflection on the effects of the more recent politics on forest-related land uses, and their consequences to regional biodiversity, is needed.

The study of the dynamics of the regional landscape could indirectly detect long-term trends in biodiversity change. The use of historical land-use and land-cover maps made possible the estimation of long-term trends in landscape connectivity, a valuable indicator of biodiversity change trends for larger periods of time than is possible by relying on direct observation methods or in remote sensing-based methods. Therefore, the insights into the long-term changes of the native forest species in the Algarve region could be considered the main contribution of the present study. Our work also contributes to facing and fixing the challenge of building extended time series maps by integrating heterogeneous sources of information. The establishment of a set of cartographic methodologies and procedures to accommodate historical and recent maps proved to be successful for the present case-study, although the computed maps and landscape metrics do not overcome the weaknesses among the time series of the maps studied (namely, a marked discontinuity between the historical agriculture and forest maps of Portugal and the recent land-cover-land-use maps of Portugal). In further developments it will be useful to apply such approach to obtain long-term time series of the distribution of other LCLUs related to biodiversity in the Algarve region, to get a more complete picture of the connectivity of the regional landscape. It may also be useful to apply the present methodological approach in studies concerning long-term time cartographic series from other parts of Portugal.

Author Contributions: Conceptualization and methodology, N.d.S.L. and M.J.F.; software and validation, resources and data curation, N.d.S.L.; formal analysis and investigation, writing-original draft preparation, review and editing, N.d.S.L. and M.J.F. All authors have read and agreed to the published version of the manuscript.

Funding: This research received no external funding.

Acknowledgments: The present study is dedicated to the geographer Luís Fraga da Silva, who recently passed away (20 March 2020), and who had the dream of seeing a revisited version of the first Carta Agrícola e Florestal de Portugal, published at a cartographic scale of 1:50,000. We offer thanks to Eng. Miguel Freitas, former Secretary of State for Forestry and Rural Development, to Landscape Archt. M. Manuela Tavares da Silva, Head of the Rural Planning Division at the Ministry of Agriculture and her entire team, for their unsurpassed collaboration in locating and accessing the chorographic-agricultural drafts for the Algarve, as well as the three finalized but never published map sheets. Without everyone's support, the present study and its results would be manifestly impossible.

Conflicts of Interest: The authors declare no conflict of interest.

\section{References}

1. Pardini, R.; Bueno, A.D.A.; Gardner, T.A.; Prado, P.I.; Metzger, J.P. Beyond the fragmentation threshold hypothesis: Regime shifts in biodiversity across fragmented landscapes. PLoS ONE 2010, 5, e13666. [CrossRef]

2. Ribeiro, J.; Colli, G.R.; Soares, A. Landscape correlates of anuran functional connectivity in rice crops: A graph-theoretic approach. J. Trop. Ecol. 2019, 35, 118-131. [CrossRef]

3. Taylor, P.D.; Fahrig, L.; Henein, K.; Merriam, G. Connectivity Is a Vital Element of Landscape Structure. Oikos 1993, 68, 571-573. Available online: http:/ /www.jstor.org/stable/3544927 (accessed on 29 September 2021). [CrossRef]

4. Ward, M.; Saura, S.; Williams, B.; Ramírez-Delgado, J.P.; Arafeh-Dalmau, N.; Allan, J.R.; Venter, O.; Dubois, G.; Watson, J.E.M. Just ten percent of the global terrestrial protected area network is structurally connected via intact land. Nat. Commun. 2020, 11, 4563. [CrossRef]

5. Siqueira, F.F.; Carvalho, D.; Rhodes, J.; Archibald, C.L.; Rezende, V.L.; Berg, E.v.d. Small Landscape Elements Double Connectivity in Highly Fragmented Areas of the Brazilian Atlantic Forest. Front. Ecol. Evol. 2021, 9, 1-14. [CrossRef]

6. Spanowicz, A.G.; Jaeger, J.A. Measuring landscape connectivity: On the importance of within-patch connectivity. Landsc. Ecol. 2019, 34, 2261-2278. [CrossRef]

7. Tischendorf, L.; Fahrig, L. On the usage and measurement of landscape connectivity. Oikos 2000, 90, 7-19. [CrossRef] 
8. Cullinan, V.I.; Thomas, J.M. A comparison of quantitative methods for examining landscape pattern and scale. Landsc. Ecol. 1992, 7, 211-227. [CrossRef]

9. Sala, O.E.; Chapin, F.S.; Armesto, J.J.; Berlow, E.; Bloomfield, J.; Dirzo, R.; Huber-Sanwald, E.; Huenneke, L.F.; Jackson, R.B.; Kinzig, A.; et al. Global Biodiversity Scenarios for the Year 2100. Science 2000, 287, 1770-1774. Available online: https: / / www.science.org/doi/10.1126/science.287.5459.1770 (accessed on 29 September 2021). [CrossRef]

10. Reddy, C.S. Remote sensing of biodiversity: What to measure and monitor from space to species? Biodivers. Conserv. 2021, 30, 2617-2631. [CrossRef]

11. Olah, B. Historical maps and their application in landscape ecological research. Ekológia 2009, 28, 143-151. [CrossRef]

12. El-Hussainy, M.S.; Baraka, M.A.; El-Hallaq, M.A. A methodology for image matching of historical maps. e-Perimetron 2011, 6, 77-95.

13. Frajer, J.; Geletič, J. Research of historical landscape by using old maps with focus to its positional accuracy. Dela 2011, 36, 49-67. [CrossRef]

14. Statuto, D.; Cillis, G.; Picuno, P. Using Historical Maps within a GIS to Analyse Two Centuries of Rural Landscape Changes in Southern Italy. Land 2017, 6, 65. [CrossRef]

15. Affek, A. Georeferencing of historical maps using GIS, as exemplified by the Austrian Military Surveys of Galicia. Geogr. Pol. 2013, 86, 375-390. [CrossRef]

16. Geri, F.; Giordano, M.; Nucci, A.; Rocchini, D.; Chiarucci, A. Multitemporal analysis of forest landscape in the province of Siena (Italy) using historical maps. Forest 2008, 5, 82-91. [CrossRef]

17. Raet, J.; Sepp, K.; Kaasik, A. Assessment of changes in forest coverage based on historical maps. For. Stud. 2008, 48, 67-78. [CrossRef]

18. United Nations Environment Programme/Mediterranean Action Plan and Plan Bleu. State of the Environment and Development in the Mediterranean; UNEP: Nairobi, Kenya, 2020.

19. Ministerio das Obras Publicas, Commercio e Industria. Carta Agricola e Estatistica Agricola Geral. Organisação e Instrucções; Imprensa Nacional: Lisboa, Portugal, 1887.

20. Roque, C.; Duarte, H.; Terrinha, P.; Valadares, V.; Noiva, J.; Cachão, M.; Ferreira, J.; Legoinha, P.; Zitellini, N. Pliocene and Quaternary depositional model of the Algarve margin contourite drifts (Gulf of Cadiz, SW Iberia): Seismic architecture, tectonic control and paleoceanographic insights. Mar. Geol. 2012, 303, 42-62. [CrossRef]

21. Kopp, E.; Sobral, M.; Soares, T.; Woerner, M. Os Solos do Algarve e as Suas Características; Vista Geral. In Direcção Regional de Agricultura do Algarve; Ministério da Agricultura, Pesca e Alimentação: Faro, Portugal, 1989.

22. Rivas-Martínez, S.; Penas, Á.; González, T.E.D.; Cantó, P.; del Río, S.; Costa, J.C.; Herrero, L.; Molero, J. Biogeographic Units of the Iberian Peninsula and Baelaric Islands to District Level. A Concise Synopsis. In The Vegetation of the Iberian Peninsula. Plant and Vegetation; Loidi, J., Ed.; Springer: Cham, Switzerland, 2017; Volume 3, pp. 131-188. [CrossRef]

23. Quinto-Canas, R.; Vila-Viçosa, C.; Paiva-Ferreira, R.; Cano-Ortiz, A.; Pinto-Gomes, C. The Algarve climatophilous vegetation series Portugal: A base document to the planning, management and nature conservation. Acta Bot. Gall. 2017, 159, 289-298. [CrossRef]

24. Reboredo, F.; Pais, J. Evolution of Forest Cover in Portugal: From the Miocene to the Present. In Forest Context and Policies in Portugal. Present and Future Challenges; Reboredo, F., Ed.; World Forests 19; Springer: Cham, Switzerland, 2014 ; pp. 1-37.

25. Silva, L.A.R. Memoria sobre a População e a Agricultura de Portugal desde a Fundação da Monarchia até 1865. Parte 1 (de 1097-1640); Imprensa Nacional: Lisboa, Portugal, 1868.

26. Magalhães, J.R. O Algarve Económico Durante o Século XVI, 2nd ed.; Sul Sol e Sal: Olhão, Portugal, 2018; (first edition in 1970).

27. Natividade, J.V. Subericultura; Ministério da Economia—Direcção Geral dos Serviços Florestais e Aquícolas: Lisboa, Portugal, 1950.

28. Mendes, A. A Economia do Sector da Cortiça em Portugal. Evolução das Actividades de Produção e Transformação ao Longo dos Séculos XIX e XX (Documento de Trabalho); Universidade Católica Portuguesa: Porto, Portugal, 2002.

29. Lains, P.; Sousa, P.S. Estatística e Produção Agrícola em Portugal, 1848-1914. Análise Soc. 1998, 149, 935-968. Available online: http:/ / analisesocial.ics.ul.pt/documentos/1221844503Z3dSG4pz7St47GS7.pdf (accessed on 21 May 2020).

30. Wu, J. Scale and Scaling: A Cross-Disciplinary Perspective. In Key Topics in Landscape Ecology; Wu, J., Hobbs, R.J., Eds.; Cambridge University Press: Cambridge, UK; New York, NY, USA, 2007; pp. 115-142.

31. Radich, M.C.; Alves, A.A.M. Dois Séculos da Floresta em Portugal; CELPA-Associação da Indústria Papeleira: Lisboa, Portugal, 2000.

32. Feio, M. A Evolução da Agricultura do Alentejo Meridional. As Cartas Agrícolas de G. Pery. As Difíceis Perspectivas Actuais na Comunidade Europeia; Edições Colibri: Lisboa, Portugal, 1998.

33. Loureiro, N.S. As Pranchetas Corográfico-Agrícolas Preparatórias da Carta Agrícola e Florestal de Portugal em 1910 Relativas ao Algarve: Uma Fonte Fundamental de Informação para a História do Uso e Ocupação do Solo na Região Algarvia. In Proceedings of the VIII Simpósio Luso-Brasileiro de Cartografia Histórica, Chaves, Portugal, 28-30 October 2019.

34. Lema, P.C. Fontes Para o Estudo da Agricultura em Portugal. Finisterra Rev. Port. De Geogr. 1971, 7, 131-141. [CrossRef]

35. SNIG. Carta de Uso e Ocupação do Solo. 1995. Available online: Snig.dgterritorio.gov.pt/rndg/srv/por/catalog.search\# / metadata/e2049ec4-0ea8-4211-bf62-64a9135777cd (accessed on 21 May 2020).

36. Di Gregorio, A.; Jansen, L.J.M. Land Cover Classification Systems (LCCS): Classification Concepts and User Manual; FAO: Rome, Italy, 1998.

37. Direção-Geral do Território, Especificações Técnicas da Carta de Uso e Ocupação do Solo de Portugal Continental Para 1995, 2007,2010 e 2015; Relatório Técnico: Lisboa, Portugal, 2018. 
38. Direção-Geral do Território. Especificações Técnicas da Carta de Uso e Ocupação do Solo (COS) de Portugal Continental Para 2018; Relatório Técnico: Lisboa, Portugal, 2019.

39. Sarmento, P.; Monteiro, G.; Marcelino, F.; Igreja, C.; Caetano, M. Avaliação da Exatidão Temática das Cartas de Uso e Ocupação do Solo para Portugal Continental COS1995v1.0, COS2007v2.0 e COS2010v1.0. Direção-Geral do Território: Lisboa, Portugal. 2016, p. 70. Available online: http://mapas.dgterritorio.pt/atom-dgt/pdf-cous/COS2007/Avaliacao_da_Exatidao_Tematica_COS.pdf (accessed on 19 May 2020).

40. CORINE. Land Cover Nomenclature Guidelines. Available online: Land.copernicus.eu/user-corner/technical-library/corineland-cover-nomenclature-guidelines/html (accessed on 21 May 2020).

41. Fuchs, R.; Herold, M.; Verburg, P.H.; Clevers, J.G.P.W. A high-resolution and harmonized model approach for reconstructing and analysing historical land changes in Europe. Biogeosciences 2013, 10, 1543-1559. [CrossRef]

42. Verburg, P.H.; Asselen, S.V.; Zanden, E.H.V.D.; Stehfest, E. The representation of landscapes in global scale assessments of environmental change. Landsc. Ecol. 2013, 28, 1067-1080. [CrossRef]

43. Calabrese, J.M.; Fagan, W.F. A comparison-shopper's guide to connectivity metrics. Front. Ecol. Environ. 2004, 2, 529-536. [CrossRef]

44. Weinholtz, F.A.B. Memoria Sobre a Economia Rural da 9. ${ }^{a}$ Região Agronómica; Typ. Burocratica: Tavira, Portugal, 1891.

45. Rodrigues, J.M.V. O Algarve e a Grande Guerra. A Questão das Subsistências (1914-1918); Sul, Sol e Sal: Olhão, Portugal, 2019.

46. Cabreira, T. O Algarve Economico; Imprensa Libanio da Silva: Lisboa, Portugal, 1918.

47. Loureiro, N.S. Sobreiros, Azinheiras, Pinheiros e Eucaliptos no Algarve, na década de 1950. Contributos cartográficos para a história do uso florestal e agro-florestal do solo no Algarve. Silva Lusit. 2018, 26, 77-113.

48. Pais, J.M.; Lima, A.M.V.; Baptista, J.F.; Jesus, M.F.M.; Gameiro, M.M. Elementos para a história do fascismo nos campos: A Campanha do Trigo: 1928-1938 (II). Análise Soc. 1978, 14, 321-389. Available online: http:/ / analisesocial.ics.ul.pt/documentos/ 1223989053Q5hNW8wm8Db11DB9.pdf (accessed on 19 May 2020).

49. Saraiva, T. Fascist Labscapes: Geneticists, Wheat, and the Landscapes of Fascism in Italy and Portugal. Hist. Stud. Nat. Sci. 2010, 40, 457-498. [CrossRef]

50. Rolo, J.A.C.; Coelho, I.S. A(s) Agricultura(s) Algarvia(s); Contributo para a Sua Caracterização no Início dos Anos 80; Comissão de Coordenação da Região do Algarve: Faro, Portugal, 1988.

51. Melo, F.P.; Pinto, S.R.; Brancalion, P.H.; Castro, P.S.; Rodrigues, R.R.; Aronson, J.; Tabarelli, M. Priority setting for scaling-up tropical forest restoration projects: Early lessons from the Atlantic Forest Restoration Pact. Environ. Sci. Policy 2013, 33, 395-404. [CrossRef]

52. Barlow, J.; Lennox, G.D.; Ferreira, J.; Berenguer, E.; Lees, A.C.; Nally, R.M.; Gardner, T.A. Anthropogenic disturbance in tropical forests can double biodiversity loss from deforestation. Nature 2016, 535, 144-147. [CrossRef]

53. Moilanen, A.; Nieminen, M. Simple connectivity measures in spatial ecology. Ecology 2002, 83, 1131-1145. [CrossRef]

54. Sánchez-Díaz, B.; Mata-Zayas, E.E. Remote sensing as indispensable technology in ecology to support the protection of biodiversity: A review. Int. J. Conserv. Sci. 2019, 10, 811-820. Available online: http://ijcs.ro/public/IJCS-19-73_Sanchez.pdf (accessed on 21 July 2021).

55. García-Álvarez, D.; Lloyd, C.D.; Delden, H.V.; Camacho-Olmedo, M.T. Thematic resolution influence in spatial analysis. An application to Land Use Cover Change (LUCC) modelling calibration. Comput. Environ. Urban Syst. 2019, 78, 101375. [CrossRef]

56. Wadoux, A.; Heuvelink, G.; de Bruin, S.; Brus, D.J. Spatial cross-validation is not the right way to evaluate map accuracy. Ecol. Model. 2021, 457, 109692. [CrossRef] 